\title{
ANALISIS FAILURE MODE EFFECT (FMEA) PADA PENGADAAN OBAT DAN PERBEKALAN KESEHATAN PADA ERA JAMINAN KESEHATAN NASIONAL DI PUSKESMAS WONOKROMO SURABAYA
}

\author{
Nuning Farida ${ }^{*}$, Amelia Lorensia ${ }^{2}$, Budhi Setianto ${ }^{3}$, Agus Aan Adriansyah ${ }^{4}$ \\ ${ }^{1,2}$ Program Studi Magister Farmasi, Fakultas Farmasi, Universitas Surabaya \\ ${ }^{3,4}$ Program Studi Kesehatan Masyarakat, Fakultas Kesehatan \\ Universitas Nahdlatul Ulama Surabaya \\ *E-mail: apotekpulosari@gmail.com
}

\begin{abstract}
Drug services in Public Healthcare are an important component whose availability influences the success of health efforts. District / City Health Office is a regional government work unit in the health sector, one of the tasks and authorities of which is to provide and manage public medicines for the district/city area. Effective pharmaceutical management in health service facilities is very important for patient welfare so risks must be identified and controlled. One of the efforts made by the City Health Office is to procure drugs using other methods that are legal according to government procurement of goods/services besides e-purchasing, which is called non-e-purchasing of drugs. Risks in the pharmaceutical supply chain are related to product discontinuity, product shortages, poor performance, patient safety, expense errors, and technological errors, all of which can result in system disruption. This study aims to determine the suitability of the plan with the realization of $e$ purchasing of drugs, identify problems that hamper the implementation of e-purchasing of drugs, determine the impact of obstacles on procurement, cost efficiency of drug procurement and determine the potential savings of drug procurement by e-purchasing for the period 2015 to 2019 by using the FMEA method, the e-purchasing data was collected at the Wonokromo Public Health Center in Surabaya. Study Failure Mode Effect (FMEA) in the procurement of drugs and UHC health supplies in Surabaya Wonokromo Health Center for the period of 2015-2019, it can be concluded that the absorption of capitation funds is more considered using the availability variable compared to the uptake of funds based on the rupiah value because the availability of more guarantees the need for treatment in the sustainable health centre. In this case, the perception of procurement actors in the analysis of UHC procurement process obstacles there are 41 obstacles, the role of E-purchasing is a very helpful system even though the implementation has not been perfect.
\end{abstract}

Keywords: Drug Procurement, Health Center, FMEA

\begin{abstract}
ABSTRAK
Pelayanan obat di puskesmas merupakan komponen penting yang ketersediaannya berpengaruh dalam keberhasilan penyelenggaraan upaya kesehatan. Dinas Kesehatan Kabupaten/Kota (DKK) merupakan satuan kerja pemerintah daerah di bidang kesehatan yang salah satu tugas dan kewenangannya adalah menyediakan dan mengelola obat publik untuk wilayah kabupaten/kota Manajemen farmasi yang efektif di sarana pelayanan kesehatan sangat penting untuk kesejahteraan pasien sehingga risiko harus diidentifikasi dan dikendalikan. Salah satu upaya yang dilakukan oleh
\end{abstract}


Dinas Kesehatan Kota adalah melakukan pengadaan obat dengan metode lain yang sah menurut peraturan pengadaan barang/jasa pemerintah selain e-purchasing yang disebut non e-purchasing obat. Risiko dalam rantai pasokan farmasi berhubungan dengan diskontinuitas produk, kekurangan produk, kinerja yang buruk, keselamatan pasien, kesalahan pengeluaran, dan kesalahan teknologi, yang semua risiko dapat mengakibatkan gangguan sistem. Penelitian ini bertujuan untuk mengetahui kesesuaian antara rencana dengan realisasi e-purchasing obat, mengidentifikasi permasalahan yang menghambat pelaksanaan e-purchasing obat, mengetahui dampak hambatan pada pengadaan, efisiensi biaya pengadaan obat dan mengetahui potensi penghematan pengadaan obat secara $e$ purchasing periode 2015 sampai dengan 2019 dengan menggunakan metode FMEA yang dilakukan pengambilan data hasil e-purcashing di Puskesmas Wonokromo Surabaya. Study Failure Mode Effect (FMEA) dalam pengadaan obat dan perbekalan kesehatan JKN di Puskesmas Wonokromo Surabaya periode 2015-2019, dapat disimpulkan bahwa Penyerapan dana kapitasi lebih dipertimbangkan menggunakan variabel ketersediaan dibandingkan dengan serapan dana berdasarkan nilai rupiah, karena ketersediaan lebih menjamin kebutuhan untuk pengobatan di puskesmas yang berkelanjutan. Dalam hal ini Persepsi dari pelaku pengadaan pada analisis hambatan proses pengadaan JKN terdapat 41 hambatan, peran dari E-purchasing merupakan sistem yang sangat membantu meskipun dalam pelaksanaannya belum sempurna.

Kata Kunci: Pengadaan Obat, Puskesmas, FMEA

\section{PENDAHULUAN}

Peraturan Menteri Kesehatan Republik Indonesia Nomor 75 Tahun 2014 Tentang Pusat Kesehatan Masyarakat yang selanjutnya disebut Puskesmas adalah fasilitas pelayanan kesehatan yang menyelenggarakan upaya kesehatan masyarakat dan upaya kesehatan perseorangan tingkat pertama, dengan lebih mengutamakan upaya promotif dan preventif, untuk mencapai derajat kesehatan masyarakat yang setinggitingginya di wilayah kerjanya. ${ }^{1}$

Upaya pemerintah dalam mewujudkan keberhasilan pembangunan kesehatan yaitu membentuk Pusat Kesehatan Masyarakat. $^{2}$ Puskesmas merupakan unit organisasi pelayanan kesehatan yang mempunyai misi sebagai pusat pengembangan pelayanan kesehatan secara menyeluruh dan terpadu untuk masyarakat yang tinggal di suatu wilayah kerja tertentu. ${ }^{2}$ Fasilitas
Kesehatan Tingkat Pertama (FKTP) merupakan fasilitas kesehatan yang melakukan pelayanan kesehatan perorangan yang bersifat non spesifikasi untuk keperluan observasi, diagnosis, perawatan, pengobatan, dan/atau pelayanan kesehatan lainnya. ${ }^{3}$ Puskesmas merupakan FKTP tingkat I yang fungsinya salah satu sebagai pengobatan

Obat merupakan komponen penting yang ketersediaannya berpengaruh dalam keberhasilan penyelenggaraan upaya kesehatan. ${ }^{4}$ Dinas Kesehatan Kabupaten/ Kota (DKK) merupakan satuan kerja pemerintah daerah di bidang kesehatan yang salah satu tugas dan kewenangannya adalah menyediakan dan mengelola obat publik untuk wilayah kabupaten/kota. ${ }^{4}$ Standar Pelayanan Kefarmasian di Puskesmas bertujuan untuk meningkatkan mutu pelayanan kefarmasian, menjamin 
kepastian hukum bagi tenaga kefarmasian, melindungi pasien dan masyarakat dari penggunaan obat yang tidak rasional dalam rangka keselamatan pasien (patient safety). ${ }^{5}$ Pengobatan yang rasional akan mengakibatkan efek terapi yang maksimal, sehingga meningkatkan tingkat kesembuhan pasien.

Manajemen farmasi yang efektif di sarana pelayanan kesehatan sangat penting untuk kesejahteraan pasien sehingga risiko harus diidentifikasi dan dikendalikan. ${ }^{4}$ Salah satu upaya yang dilakukan oleh Dinas Kesehatan Kota adalah melakukan pengadaan obat dengan metode lain yang sah menurut peraturan pengadaan barang/jasa pemerintah selain $e$ purchasing yang disebut non e-purchasing obat. ${ }^{6}$ Risiko dalam rantai pasokan farmasi berhubungan dengan diskontinuitas produk, kekurangan produk, kinerja yang buruk, keselamatan pasien, kesalahan pengeluaran, dan kesalahan teknologi, yang semua risiko dapat mengakibatkan gangguan sistem. ${ }^{7}$

Dalam analisis risiko, ada beberapa metode yang dapat digunakan, salah satunya adalah Failure Mode and Effect Analysis (FMEA). ${ }^{8}$ Ariani et al. (2016) menganalisis penggunaan FMEA dalam tahap desain $e$ procurement, agar dapat diketahui risiko yang mungkin terjadi dan dapat dikembangkan tindakan untuk mencegah risiko tersebut ketika e-procurement telah diterapkan. ${ }^{7}$ FMEA dipilih karena fleksibilitasnya, sehingga metode ini banyak dilakukan di beberapa produk atau proses. $^{9}$ Selain itu, metode ini dapat mengidentifikasi potensi permasalahan pada proses, kontrol proses, dan mengidentifikasi apa yang bisa salah ketika sebuah proses benarbenar dijalankan, yang akan memungkinkan kesempatan untuk mengurangi masalah sebelum terjadi. ${ }^{6}$

FMEA digunakan untuk mengidentifikasi kemungkinan kesalahan sebelum terjadi. Pendekatan ini memungkinkan masing-masing elemen dari proses yang akan dikaitkan nilai numerik kumulatif yaitu RPN (Risk Priority Number) yang kemudian digunakan untuk memprioritaskan tindakan yang diambil terhadap elemen yang telah di identifikasi. Potensi risiko masing-masing elemen dari proses dihitung dengan interpretasi tiga indeks yaitu saverity (akibat kesalahan), Occurance (kemungkinan kesalahan terjadi) dan detection (kesalahan berpeluang). Level indeks ini yang akan menghasilkan nilai RPN. ${ }^{7}$

FMEA secara khusus sebagai alat evaluasi memiliki karakter yang terdiri dari; identifikasi dan evaluasi mode kegagalan, mode produk atau kegagalan proses dan konsekuensinya; identifikasi dari tindakan yang dapat menghilangkan kemungkinan terjadinya modus kegagalan sebelum diidentifikasi; dan dokumentasi hasil. ${ }^{7}$ Penelitian ini bertujuan untuk mengetahui kesesuaian antara rencana dengan realisasi $e$ purchasing obat, mengidentifikasi permasalahan yang menghambat pelaksanaan e-purchasing obat, mengetahui dampak hambatan pada 
pengadaan, efisiensi biaya pengadaan obat dan mengetahui potensi penghematan pengadaan obat secara e-purchasing periode 2015 sampai dengan 2019 dengan menggunakan metode FMEA yang dilakukan pengambilan data hasil e-purcashing di Puskesmas Wonokromo Surabaya.

\section{METODE PENELITIAN}

Rancangan penelitian yang digunakan dalam penelitian ini adalah rancangan penelitian deskriptif kuantitatif dengan metode diskusi dan kuesioner/angket. Penelitian observasi digunakan dengan mengolah data dari penerimaan dana kapitasi dibandingkan dengan penyerapan kapitasi untuk pengadaan kefarmasian (obat dan perbekkes) di Puskesmas Wonokromo Surabaya periode 2015-2019. Penelitian diskusi untuk mengetahui hambatanhambatan yang terjadi pada pengadaan. Analisis identifikasi faktor hambatan tersebut dirancang dalam kuesioner yang merupakan variabel yang digunakan untuk menganalisis faktor terbesar yang berpengaruh terhadap rendahnya penyerapan dana kapitasi kefarmasian dengan metode FMEA

Penelitian yang dilakukan terkait persepsi dari pelaku pengadaan yang berperan dalam proses pengadaan yaitu dengan melakukan diskusi. Pelaku pengadaan yang dimaksud dalam penelitian ini adalah:

a. Bendahara JKN di Puskesmas Wonokromo untuk proses perencanaan, penerimaan, perencanaan dan penyerapan dana kapitasi (Partisipan 1)

b. Staf Apoteker seksi kefarmasian di Dinas Kesehatan Kota Surabaya untuk proses pengadaan (Partisipan 2)

c. Apoteker Penanggung Jawab PBF di distributor obat/PBF untuk proses ketersediaan obat dan perbekkes dan distribusi (Partisipan 3)

d. Staf Apoteker GFK di Gudang Farmasi untuk proses distribusi ke Puskesmas Wonokromo (Partisipan 4)

\section{HASIL DAN PEMBAHASAN}

Pelaku pengadaan selanjutnya disebut sebagai partisipan. Partisipan memberikan gambaran dengan membuat bagan alur untuk mempermudah dalam menganalisis masingmasing hambatan, dana kapitasi berdasarkan jumlah ke pesertaan yang terdaftar pada FKTP Puskesmas Wonokromo, diterima oleh Bendahara Puskesmas, Kepala Puskesmas sebagai penanggung jawab dan dimonitor oleh Dinas Kesehatan Kota Surabaya. Analisis hambatan penerimaan dana kapitasi beserta koding pada proses penerimaan dana kapitasi ditampilkan dalam Tabel 1. 
Tabel 1. Identifikasi Implementasi dan Tujuan Kebijakan yang Terkait dengan Proses Penerimaan Dana Kapitasi di Puskesmas Wonokromo Surabaya

\begin{tabular}{|c|c|c|c|c|}
\hline No. & Kebijakan & $\begin{array}{l}\text { Implementasi } \\
\text { Kebijakan }\end{array}$ & Tujuan Kebijakan & $\begin{array}{c}\text { Gap Implementasi } \\
\text { Kebijakan }\end{array}$ \\
\hline a. & $\begin{array}{l}\text { PMK. No. } 28 \text { Tahun } \\
2014 \text { tentang Pedoman } \\
\text { Pelaksanaan Program } \\
\text { JKN }\end{array}$ & $\begin{array}{l}\text { Dibayarkan pada mid } \\
\text { bulan }\end{array}$ & $\begin{array}{l}\text { BPJS memberikan } \\
\text { hak kapitasi kepada } \\
\text { FKTP }\end{array}$ & $\begin{array}{l}\text { Penambahan peserta akan } \\
\text { dibayarkan pada bulan } \\
\text { selanjutnya } \\
\text { susulan. }\end{array}$ \\
\hline b. & $\begin{array}{l}\text { Kebijakan norma } \\
\text { kapitasi di Puskesmas } \\
\text { Wonokromo }\end{array}$ & $\begin{array}{l}\text { Keaktifan kepesertaan } \\
\text { sangat berpengaruh } \\
\text { pada pelayanan } \\
\text { petugas puskesmas }\end{array}$ & $\begin{array}{l}\text { Pelayanan pada } \\
\text { masyarakat dengan } \\
\text { sepenuh hati. }\end{array}$ & $\begin{array}{l}\text { peserta memiliki hak } \\
\text { untuk berpindah FKTP } \\
\text { dan ini akan mengurangi } \\
\text { jumlah kepesertaan, dana } \\
\text { kapitasi yang diterima } \\
\text { juga akan berkurang }\end{array}$ \\
\hline c. & $\begin{array}{lr}\text { Kebijakan } & \text { transfer } \\
\text { pembayaran } & \text { dana } \\
\text { kapitasi } & \end{array}$ & $\begin{array}{l}\text { Jumlah peserta yang } \\
\text { terdaftar dapat dilihat } \\
\text { pada aplikasi } p \text {-care }\end{array}$ & $\begin{array}{l}\text { Memastikan jumlah } \\
\text { terdaftar sesuai } \\
\text { dengan pembayaran } \\
\text { kapitasi }\end{array}$ & $\begin{array}{l}\text { Aplikasi p-care kadang } \\
\text { error tidak bisa login. }\end{array}$ \\
\hline d & $\begin{array}{lr}\text { Kebijakan MenKes No } \\
19 \text { tahun } 2014 \text { tentang } \\
\text { penggunaan } & \text { dana } \\
\text { kapitasi } & \text { jaminan } \\
\text { kesehatan } & \text { nasional } \\
\text { untuk jasa } & \text { pelayanan } \\
\text { kesehatan } & \text { dan } \\
\text { dukungan } & \text { biaya } \\
\text { operasional } & \text { pada } \\
\text { FKTP } & \\
\end{array}$ & $\begin{array}{lr}\text { Kepala } & \text { Puskesmas } \\
\text { bertanggung } & \text { jawab } \\
\text { sepenuhnya } & \text { atas } \\
\text { penggunaan } & \text { dana } \\
\text { kapitasi JKN } & \end{array}$ & $\begin{array}{l}\text { Memastikan tidak } \\
\text { ada penyelewengan } \\
\text { penggunaan dana } \\
\text { kapitasi JKN }\end{array}$ & $\begin{array}{l}\text { Puskesmas yang belum } \\
\text { BLUD tidak dapat } \\
\text { fleksibel mengelola } \\
\text { keuangan JKN. }\end{array}$ \\
\hline $\mathrm{e}$ & $\begin{array}{l}\text { Kebijakan } \\
\text { pengambilan } \\
\text { keputusan pengelolaan } \\
\text { dana kapitasi harus } \\
\text { mengetahui Dinas } \\
\text { Kesehatan }\end{array}$ & $\begin{array}{l}\text { Peran Dinas Kesehatan } \\
\text { sebagai payung hukum }\end{array}$ & \begin{tabular}{lr}
\multicolumn{2}{l}{ Memastikan } \\
pertanggungjawab- \\
an & Kepala \\
Puskesmas & dalam \\
menggunakan & dana \\
kapitasi ras & sesuai \\
dengan Undang- & undang yang berlaku
\end{tabular} & $\begin{array}{l}\text { Pencairan dana tidak bisa } \\
\text { dilakukan jika pejabat } \\
\text { Dinas Kesehatan tidak } \\
\text { berada di tempat dinas, }\end{array}$ \\
\hline
\end{tabular}

Tabel 1 menjelaskan perencanaan obat dan perbekalan kesehatan Puskesmas Wonokromo dilakukan oleh Apoteker Penanggung jawab yang disetujui oleh Kepala Puskesmas. Perencanaan yang di buat berdasarkan metode konsumtif yaitu berdasarkan pemakaian pada tahun sebelumnya dengan buffer stok sebesar 50 persen.

Apoteker penanggung jawab menerima usulan dari masing-masing poli pelayanan. Hasil usulan tersebut di buat dalam laporan Rencana Kebutuhan Obat (RKO). RKO yang dirancang 
dan diketahui oleh Kepala Puskesmas diajukan ke Dinas Kesehatan Kota Surabaya, yang ditindaklanjuti dengan beakdown usulan berdasarkan sumber pembiayaan pengadaan, yaitu; sumber dana dari DAK, Program, APBD dan JKN. Pembiayaan pengadaan menggunakan JKN akan dikembalikan ke puskesmas untuk di buatkan entri RKA

Pengadaan yang dianalisis oleh peneliti adalah pengadaan dengan e-purchasing yang merupakan persyaratan pembelian dengan dana JKN. Pembelian dengan pengadaan langsung, penunjukan langsung, tender cepat dan tender tidak dianalisis oleh peneliti karena pembelian tersebut menggunakan dana yang bersumber dari DAK dan APBD. Setelah pengesahan SPK maka industri farmasi akan memenuhi ketersediaan obat dan perbekkes, dilanjutkan dengan distribusi ke PBF. Dari PBF maka distribusi diteruskan ke Gudang Farmasi Kota Surabaya. Distribusi ke GFK berdasarkan jumlah total tender puskesmas se-Surabaya.

Pada penelitian ini terdapat beberapa hambatan yang terjadi pada tahapan proses pengadaan, berikut adalah analisis hambatan beserta koding yang ditampilkan pada Tabel 2 .

Tabel 2. Identifikasi Implementasi dan Tujuan Kebijakan yang Terkait dengan Pengadaan Obat dan Perbekkes Di Puskesmas Wonokromo Surabaya

\begin{tabular}{|c|c|c|c|c|}
\hline No & Kebijakan & $\begin{array}{c}\text { Implementasi } \\
\text { Kebijakan }\end{array}$ & Tujuan Kebijakan & $\begin{array}{c}\text { Gap Implementasi } \\
\text { Kebijakan }\end{array}$ \\
\hline a. & $\begin{array}{l}\text { Kebijakan } \\
\text { pemilihan PBF } \\
\text { dalam pengadaan } \\
\text { e-purchasing }\end{array}$ & $\begin{array}{l}\text { PBF tidak mengetahui } \\
\text { secara langsung } \\
\text { penunjukan distribusi } \\
\text { dalame-purchasing }\end{array}$ & $\begin{array}{l}\text { Penerapan CDOB } \\
\text { (Cara Distribusi Obat } \\
\text { yang Baik) }\end{array}$ & $\begin{array}{l}\text { Tidak akan mengetahui } \\
\text { sebelum ada informasi dari } \\
\text { pihak industri farmasi } \\
\text { sebagai penunjukkan } \\
\text { distributor e-purchasing. }\end{array}$ \\
\hline b. & $\begin{array}{l}\text { PMK No. } 63 \text { tahun } \\
2014 \text { tentang } \\
\text { pengadaan obat } \\
\text { berdasarkan } \\
\text { katalog }\end{array}$ & $\begin{array}{l}\text { Kebijakan } \\
\text { pertimbangan yang } \\
\text { menjadi } \quad \text { kriteria } \\
\text { penunjukan PBF }\end{array}$ & $\begin{array}{lr}\text { PBF yang } & \text { dipilih } \\
\text { memenuhi } & \\
\text { persyaratan } & e- \\
\text { purchasing } & \text { dengan } \\
\text { ketentuan } & \text { yang } \\
\text { berlaku } & \end{array}$ & $\begin{array}{l}\text { Persyaratan PBF yang } \\
\text { memenuhi syarat } e- \\
\text { purchasing salah satunya } \\
\text { mudah koordinasi dalam } \\
\text { kerja sama, pengiriman yang } \\
\text { sesuai waktu yang } \\
\text { ditentukan yang dituangkan } \\
\text { dalam SPK. }\end{array}$ \\
\hline c. & $\begin{array}{l}\text { PMK No. } 63 \text { tahun } \\
2014 \text { tentang } \\
\text { pengadaan obat } \\
\text { berdasarkan } \\
\text { katalog }\end{array}$ & $\begin{array}{l}\text { Dinas Kesehatan yang } \\
\text { berwenang melakukan } \\
\text { pengadaan untuk } \\
\text { memberikan } \\
\text { persetujuan atas } \\
\text { permintaan pembelian } \\
\text { obat dan menunjuk } \\
\text { distributor/PBF. }\end{array}$ & $\begin{array}{l}\text { Memenuhi } \\
\text { ketersediaan } \\
\text { pemesanan } \\
\text { purchasing }\end{array}$ & $\begin{array}{l}\text { distributor obat tidak pernah } \\
\text { membuat penolakan karena } \\
\text { jika ini terjadi maka backlist } \\
\text { industri farmasi akan } \\
\text { diberlakukan untuk tidak } \\
\text { diperbolehkan mengikuti } \\
\text { tender e-purchasing pada } \\
\text { tahun berikutnya. } \\
\text { Distributor dan Industri } \\
\text { Farmasi memilih } \\
\text { mendapatkan sangsi denda } \\
\text { daripada di backlist. }\end{array}$ \\
\hline
\end{tabular}




\begin{tabular}{|c|c|c|c|c|}
\hline No & Kebijakan & $\begin{array}{l}\text { Implementasi } \\
\text { Kebijakan }\end{array}$ & Tujuan Kebijakan & $\begin{array}{l}\text { Gap Implementasi } \\
\text { Kebijakan }\end{array}$ \\
\hline $\mathrm{d}$ & $\begin{array}{l}\text { Kebijakan Surat } \\
\text { Perintah Kerja dari } \\
\text { Dinas Kesehatan }\end{array}$ & $\begin{array}{l}\text { Sangsi pelanggaran } \\
\text { yang dilakukan oleh } \\
\text { dinas (Pejabat Pembuat } \\
\text { Komitmen) }\end{array}$ & $\begin{array}{l}\text { Memenuhi } \\
\text { ketersediaan } \\
\text { pemesanan } \\
\text { purchasing }\end{array}$ & $\begin{array}{l}\text { Sangsi pelanggaran yang } \\
\text { dilakukan oleh dinas(PPK) } \\
\text { sangat berat, oleh karena itu } \\
\text { SPK dibuat sedemikian } \\
\text { sesuai dengan undang- } \\
\text { undang yang ditetapkan }\end{array}$ \\
\hline
\end{tabular}

Tabel 2 menjelaskan dampak yang paling sering terjadi pada fasilitas pelayanan akibat hambatan pada pelaksanaan e-purchasing obat adalah terjadinya kekosongan obat untuk pelayanan, ketidak tersediaan obat untuk pelayanan dan potensi inefisiensi anggaran penyediaan obat akibat tidak terpenuhinya pengadaan obat secara e-purchasing. ${ }^{8}$ Hasil rekapitulasi analisis hambatan pada proses pengadaan JKN di Puskesmas Wonokromo periode 2015-2019 terdapat 41 hambatan. Total hambatan tersebut dilakukan penilaian Risk Priority Number $(\mathrm{RPN}=$ Saverity $x$ Occurance $x$ Detection) yang diperoleh dari kuesioner responden pada masing-masing instansi.

Hasil penelitian terdapat 37 hambatan dengan RPN $<150$ dan terdapat 4 hambatan dengan nilai RPN > 150. Hambatan dengan RPN > 150 yaitu alur perencanaan dana kapitasi terdapat nilai RPN sebesar 240 risiko kegagalan terdapat pada sub alur adanya keterbatasan permintaan kebutuhan yang mengacu pada fornas dan RPN sebesar 315 terdapat pada sub proses variant kasus yang bisa di tangani di puskesmas tetapi ketersediaan obat nihil karena tidak ada dalam daftar fornas. Alur pengadaan obat perbekkes terdapat nilai RPN sebesar 360 terdapat pada sub alur ketersediaan pada ekatalog jumlah yang ditayangkan tidak sesuai dengan fisik yang dimiliki oleh pabrikan dan nilai RPN sebesar 225 terdapat pada sub alur stok yang ditayangkan hanya dapat memberikan gambaran pemenuhan ketersediaan obat yang dibutuhkan. Suatu risiko dikategorikan pada risiko kritis jika memiliki nilai RPN di atas nilai kritis. Nilai kritis RPN ditentukan dari nilai-nilai RPN dari seluruh risiko. ${ }^{10}$

Hambatan yang diidentifikasi selanjutnya ditetapkan cut off point RPN, di mana mode kegagalan atau item dengan RPN di atas titik itu memerlukan perhatian lebih lanjut, selanjutnya Pareto Chart untuk perbandingan RPN antara mode kegagalan yang berbeda diberikan pada hambatan yang diidentifikasi. ${ }^{11}$ Pareto berguna untuk mengidentifikasi kejadian-kejadian atau penyebab masalah yang paling umum, yang didasarkan pada hukum 80/20 yang berarti bahwa $80 \%$ kerugian hanya disebabkan oleh hanya $20 \%$ masalah tersebar. ${ }^{12}$

Hasil perhitungan cut off point dengan menggunakan pareto terdapat 3 hambatan terbesar yaitu pada alur sub proses keterbatasan permintaan kebutuhan yang mengacu pada fornas, variant kasus yang bisa di tangani di 
puskesmas tetapi ketersediaan obat nihil karena tidak ada dalam daftar fornas dan ketersediaan pada e-katalog jumlah yang ditayangkan tidak sesuai dengan fisik yang dimiliki oleh pabrikan/industri farmasi. Hanif et al. 2015 dalam penelitiannya Perbaikan Kualitas Produk Keraton Luxury Dengan Menggunakan Metode Failure Mode AndEffect Analysis (FMEA) berdasarkan pengolahan data menggunakan konsep pareto, proses yang memiliki biaya rework terbesar terdapat pada masalah pada pembuatan Keraton Luxury adalah membelah kayu, dan proses pemberian cat dasar. ${ }^{13}$

Upaya Redesign Proses dengan menghilangkan Failure Mode dari 41 implementasi kebijakan dalam proses alur pengadaan obat perbekkes yang menjadi prioritas utama dalam upaya perbaikan adalah sebagai berikut:

1. Proses alur penggunaan dana kapitasi di Puskesmas Wonokromo hambatan terbesar berada pada keterbatasan permintaan kebutuhan yang mengacu pada fornas variant kasus yang bisa di tangani di puskesmas tetapi ketersediaan obat nihil karena tidak ada dalam daftar fornas dengan usulan redesign peneliti sebagai berikut:

a. Mengagendakan sosialisasi tentang fornas kepada Tenaga Kesehatan lainnya

b. Kebijakan ketersediaan kebutuhan puskesmas diluar Fornas, karena kebutuhan setiap puskesmas akan berbeda c. Evaluasi terhadap permintaan di luar fornas yang tidak sebanding kasus yang ditangani di puskesmas

d. Peresepan non-fornas yang bervariasi

e. Kasus ringan yang terjadi di puskesmas tidak sebanding dengan kebijakan kasus yang dapat dirujuk ke FKTL

f. Kasus yang dapat ditangani di FKTP tidak tersedia jenis obat untuk terapi pengobatan

g. Pelaksanaan program JKN yang berpotensi meningkatkan kebutuhan obat di FKTP

2. Proses pengadaan obat perbekkes oleh Dinas Kesehatan Kota Surabaya hambatan terbesar berada pada ketersediaan obat perbekkes pada e-katalog jumlah yang ditayangkan tidak sesuai dengan fisik yang dimiliki oleh pabrikan dengan usulan redesign peneliti sebagai berikut:

a. Upgrade web e-katalog dengan lebih terperinci

b. Terdapat pengurangan stok pada tayangan e-katalog baik dalam proses pemesanan maupun telah selesai tender

c. Tidak tersedia distributor yang akan dilakukan distribusi

Metode FMEA pada pelayanan farmasi rumah sakit mengenai "Redesign Pelayanan Farmasi Dengan Metode Failure Mode and Effect Analysis (FMEA)" menemukan bahwa kegagalan Risk Priority Number (RPN) tertinggi adalah kegagalan dalam konfirmasi petugas 
Apoteker ke Dokter dan diikuti kegagalan dalam mendeteksi nama obat dalam proses prescribing $\operatorname{resep}^{4,6}$.

\section{SIMPULAN DAN SARAN}

\section{Simpulan}

Study Failure Mode Effect (FMEA) dalam pengadaan obat dan perbekalan kesehatan JKN di Puskesmas Wonokromo Surabaya periode 2015-2019, dapat disimpulkan bahwa Penyerapan dana kapitasi lebih dipertimbangkan menggunakan variabel ketersediaan dibandingkan dengan serapan dana berdasarkan nilai rupiah, karena ketersediaan lebih menjamin kebutuhan untuk pengobatan di puskesmas yang berkelanjutan.

\section{Saran}

Persepsi dari pelaku pengadaan pada analisis hambatan proses pengadaan JKN terdapat 41 hambatan, peran dari E-purchasing merupakan sistem yang sangat membantu meskipun dalam pelaksanaannya belum sempurna.

\section{REFERENSI}

1. Permenkes RI. Permenkes Nomor 75 Tahun 2014 Tentang Pusat Kesehatan Masyarakat. 2014;561-5.

2. Malasai DD, Maramis FRR, Kawatu PAT, Kesehatan F, Universitas M, Ratulangi S. Analisis Pelaksanaan Perencanaan Dan Pengadaan Obat Di Puskesmas Modayag. 2016;1-11.

3. Permenkes RI. Peraturan Pemerintah Kesehatan RI no.63 Tahun 2014 Tentang Pengadaan Obat Berdasarkan Katalog
Elektronk (E-Catalogue). Menteri Kesehatan Republik Indonesia; 2014.

4. Kusmini K, Satibi S, Suryawati S. Evaluasi Pelaksanaan E-Purchasing Obat Pada Dinas Kesehatan Kabupaten/Kota Di Jawa Tengah Tahun 2015. J Manaj DAN PELAYANAN Farm (Journal Manag Pharm Pract. 2018;6(4):277.

5. Permenkes. Peraturan Menteri Kesehatan Republik Indonesia Nomor 74 Tahun 2016 Tentang Standar Pelayanan Kefarmasian Di Puskesmas. 2016;3(1):56.

6. Nibong C. Analisis Perencanaan Dan Pengadaan Obat Di Puskesmas Sario Kota Manado Universitas Sam Ratulangi. 2019;6(3):1-12. Available from: http://www.ejournalhealth.com/index.php/ kesmas/article/view/451

7. Pertiwi H. Pertiwi, Havea. Implementasi Manajemen Risiko Berdasarkan PMBOK Untuk Mencegah Keterlambatan Proyek Area Jawa Timur ( Studi Kasus: PT . Telkom). 2017;4(2):96-108.

8. Irawan J. Model Analisis dan Strategi Mitigasi Risiko Produksi Keripik Tempe Model Analysis and Mitigation Strategy of Risk in Tempe Chips Production. 2017;2(2):88-96.

9. Irawan JP, Santoso I, Mustaniroh SA. Model Analisis dan Strategi Mitigasi Risiko Produksi Keripik Tempe Model Analysis and Mitigation Strategy of Risk in Tempe Chips Production. 2017;6(2):88-96.

10. Roohollah A. Failure Mode And Effect Analysis: Improving Intensive Care Unit Risk Management Processes. International Journal of Health Care Quality Assurance. 2019;11(7):216-21.

11. Howard L. Failure mode and effects analysis drastically reduced potential risks in clinical trial conduct. Drug Design, Development and Therapy. 2017;11:303543.

12. Hoori A. Evaluating the application of failure mode and effects analysis technique 
MTPH Journal, Volume 5, No. 1, March 2021

ISSN: 2549-189X; e-ISSN: 2549-2993

in hospital wards: a systematic review. Journal of Injury and Violence Research. 2017;9(1):51-60.

13. Li X. Application of failure mode and effect analysis in managing catheter-related blood stream infection in intensive care unit. 2017.

14. Gunardi Ayud, Kedokteran F, Ilmu dan, Farmasi PS. Penerapan Failure Mode And Effect Analysis (FMEA) Untuk Mendeteksi Prescription Error Pada Resep Poli Jantung Di Instalasi Rawat Jalan RSUP Fatmawati. 2015. 